\title{
Rola krótkołańcuchowych kwasów tłuszczowych w nieswoistych chorobach zapalnych jelit i raku jelita grubego
}

\section{STRESZCZENIE}

$\mathbf{K}^{\mathrm{s}}$ rótkołańcuchowe kwasy tłuszczowe (SCFA) są wytwarzane w wyniku beztlenowej fermentacji bakteryjnej w okrężnicy i uważa się, że mają one działanie ochronne w odniesieniu do chorób przewodu pokarmowego. SCFA, takie jak octan, propionian i maślan, są ważnymi metabolitami w utrzymaniu homeostazy jelitowej oraz udowodniono ich korzystne działanie w przypadku nieswoistych chorób zapalnych jelit oraz raka jelita grubego. SCFA są odpowiedzialne za utrzymanie prawidłowej bariery jelitowej oraz wykazują liczne funkcje immunomodulujące. Swoje działanie SCFA wykazują głównie przez aktywację receptorów sprzężonych z białkiem $\mathrm{G}$ na powierzchni komórki (GPCR), takich jak GPR41, GPR43 i GPR109A. W niniejszym artykule przeglądowym omówimy metabolizm i mechanizm działa SCFA oraz ich wpływ na błonę śluzową jelit ze szczególnym naciskiem na ich znaczenie dla chorób zapalnych i raka jelita grubego.

\section{WPROWADZENIE}

Krótkołańcuchowe kwasy tłuszczowe (ang. short-chain fatty acids, SCFA), znane również jako lotne kwasy tłuszczowe, zbudowane są z łańcuchów zawierających od jednego do sześciu atomów węgla. W organizmie człowieka najliczniejsze SCFA ( $\geq 95 \%$ ) to octan (C2), propionian (C3) i maślan (C4) [1]; ich stosunek molowy wynosi w przybliżeniu 60:20:20 [2]. Inne SCFA, takie jak mrówczan (C1), walerianian (C5) i kapronian (C6) występują w organizmie w znacznie mniejszych ilościach. Niewielkie ilości SCFA są pozyskiwane bezpośrednio z pożywienia, jednak ich głównym źródłem jest fermentacja błonnika pokarmowego w okrężnicy. Każdego dnia w jelicie produkowanych jest około 500-600 mmol SCFA, jednakże wartość ta jest zależna od wielu czynników, takich jak ilość dostarczanego błonnika, czas pasażu jelitowego oraz skład mikrobioty jelitowej [3] (Tabela 1).

Istnieje wiele dowodów potwierdzających, że SCFA mają plejotropowy wpływ na zdrowie i homeostazę organizmu człowieka, między innymi obniżają poziom cholesterolu we krwi i działają przeciwcukrzycowo poprzez pobudzenie wysp trzustki do wydzielania insuliny co prowadzi do obniżenia poziomu glukozy. $[5,6]$. Ponadto SCFA mają wpływ na aktywację brunatnej tkanki tłuszczowej, zapobiegając otyłości spowodowanej dietą wysokotłuszczową, insulinooporności oraz stłuszczeniu wątroby. Dodatkowo, zmniejszają wewnątrzkomórkową aktywację lipidów oraz stres oksydacyjny poprzez działanie przede wszystkim maślanu i jego syntetycznej pochodnej N-(1-karbamoilo-2-fenyloetylo) butyramidu na mitochondria w wątrobie. SCFA pozytywnie wpływają również na sen, głównie poprzez wydłużanie fazy NREM [7,8].

Dodatkowo, SCFA istotnie poprawiają funkcję i pracę jelit. Biorą udział w utrzymaniu integralności bariery jelitowej, chronią przed zapaleniem, zwiększają produkcję śluzu, a także stymulują motorykę jelita [9-11]. Liczne prace sugerują ich ochronne oraz prozdrowotne działanie w patologiach przewodu pokarmowego, takich jak nieswoiste choroby zapalne jelit (NChZJ) oraz rak jelita grubego (Ryc. 1).

Nieswoiste choroby zapalne jelit (NChZJ) to grupa wieloczynnikowych chorób, charakteryzujących się przewlekłym stanem zapalnym w przewodzie pokarmowym. Do NChZJ zaliczamy chorobę Leśniowskiego-Crohna (ChLC), która może dotyczyć każdego odcinka przewodu pokarmowego oraz wrzodziejące zapalenie jelita grubego (WZJG), które ogranicza się do jelita grubego [12]. Obie

RNA); TNFa - czynnik martwicy nowotworów (ang. tumor necrosis factor a); WT - dziki typ (ang. wild type); Stat3 - przetwornik sygnału i aktywator transkrypcji 3 (ang. signal transducer and activator of transcription 3); TLR - receptory Toll-podobne (ang. toll-like receptors); IFN - interferon; mTOR - ssaczy cel rapamycyny (ang. mammalian target of rapamycin)

Finansowanie: Fundacja na rzecz Nauki Polskiej (POIR.04.04.00-00-420C/17-02; JF) i Uniwersytet Medyczny w Łodzi (503/1-156-04/503-11-001-19; JF).

\section{Jakub Włodarczyk ${ }^{\bigotimes}$,}

Martyna Płoska,

\section{Karol Płoski,}

\section{Jakub Fichna}

Zakład Biochemii, Uniwersytet Medyczny w Łodzi, ul. Mazowiecka 6/8, 92-215 Łódź

https://doi.org/10.18388/pb.2021_396

๑autor korespondujący: jakub.wlodarczyk@ stud.umed.lodz.pl

Słowa kluczowe: krótkołańcuchowe kwasy tłuszczowe, mikrobiota, rak jelita grubego, nieswoiste choroby zapalne jelit.

Wykaz skrótów: SCFA - krótkołańcuchowe kwasy tłuszczowe; NChZJ - nieswoiste choroby zapalne jelit; ChLC - choroba Leśniowskiego-Crohna; WZJG - wrzodziejące zapalenie jelita grubego; RJG - rak jelita grubego; GPCR - Receptor sprzężony z białkiem G (ang. G protein Coupled Receptor); FFAR - receptor wolnych kwasów tłuszczowych (ang. free fatty acid receptor); GPR41 - Receptor sprzężony z białkiem G 41 (ang. G protein coupled receptor 41); GPR43 - Receptor sprzężony z białkiem G 43 (ang. G protein coupled receptor 43); GPR109a - Receptor sprzężony z białkiem G 109a (ang. G protein coupled receptor 109a); HCA2 - receptor kwasu hydroksykarboksylowego 2 (ang. hydroxycarboxylic acid receptor 2); MCT - transporter monokarboksylowy zależny od protonów (ang. proton-dependent monocarboxylate transporter); SMCT - transporter monokarboksylanu zależny od sodu (ang. sodium-dependent monocarboxylate transporter); NREM - sen wolnofalowy (ang. non-rapid eye movement); NLRP3 - białko NOD-podobne 3, zawierające domenę pirynową (ang. NOD-like receptor family, pyrin domain containing 3 ); iNOS - indukowalna syntaza tlenku azotu (ang. inducible nitric oxide synthase); DSS - dekstran siarczanu sodu; NF-kb - czynnik jądrowy kappa-wzmacniacz łańcucha lekkiego aktywowanych komórek B (ang. nuclear factor kappa-light-chain-enhancer of activated B cells); LPS - lipopolisacharyd; PTX - toksyna krzuścowa (ang. pertussis toxin); DC - komórki dendrytyczne; AhR - receptor węglowodorów arylowych; HIF1a - czynnik indukowany hipoksją 1a; IDO1 - 2,3-dioksygenaza indoloaminowa 1; Aldh1A2 - dehydrogenaza aldehydowa 1A2, HDAC - deacetylaza histonowa (ang. histone deacetylase); siRNA mały interferujący RNA (ang. small interfering 
Tabela 1. Źródła krótkołańcuchowych kwasów tłuszczowych dla organizmu. [4]

\begin{tabular}{|c|c|c|}
\hline Substrat & Źródła w diecie & Fermentujące drobnoustroje \\
\hline Fruktoza & Nektar z agawy, miód, owoce & $\begin{array}{l}\text { Lactobacillus } \\
\text { Bifidobacterium } \\
\text { Faecalibacterium }\end{array}$ \\
\hline Glukoza & Jabłka, maliny, groch zielony & Faecalibacterium \\
\hline Amyloza & Ziemniak, kukurydza, pszenica, tapioka, ryż & $\begin{array}{l}\text { Bifidobacterium } \\
\text { Eubacterium } \\
\text { Ruminococcus } \\
\text { Prevotella }\end{array}$ \\
\hline B-Glukan & Owies, jęczmień, pszenica, żyto, grzyby, wodorosty & $\begin{array}{l}\text { Eubacterium } \\
\text { Atopobium } \\
\text { Enterococcus } \\
\text { Lactobacillus } \\
\text { Prevotella } \\
\text { Clostridium cluster XIVa }\end{array}$ \\
\hline Guma arabska & Akacja, gotowy dodatek do żywności & $\begin{array}{l}\text { Bifidobacterium } \\
\text { Lactobaciullus } \\
\text { Ruminococcus }\end{array}$ \\
\hline Guma guar & Fasola guar, gotowy dodatek do żywności & $\begin{array}{l}\text { Bifidobacterium } \\
\text { Ruminococcus }\end{array}$ \\
\hline Inulina & Szparagi, por, cebula, banan, pszenica, czosnek & $\begin{array}{l}\text { Bifidobacterium } \\
\text { Faecalibacterium }\end{array}$ \\
\hline Celuloza & Wodorosty, otręby pszenne & Bifidobacterium \\
\hline Pektyna & Jabłka, morele, wiśnie, pomarańcze, marchewki & Eubacterium \\
\hline Laktoza & Mleko, jogurty, maślanka, sery & $\begin{array}{l}\text { Lactobacillus } \\
\text { Bifidobacterium } \\
\text { Streptococcus } \\
\text { Escherichia coli }\end{array}$ \\
\hline Rafinoza & $\begin{array}{l}\text { Mąka z nasion bawełny, mąka sojowa, cebula, } \\
\text { ciecierzyca, fasola, groch, soczewica }\end{array}$ & $\begin{array}{l}\text { Lactobacillus } \\
\text { Bifidobacterium }\end{array}$ \\
\hline Mannitol & $\begin{array}{l}\text { Marchew, szparagi, oliwki słodkie ziemniaki, } \\
\text { ananas, grzyby, wodorosty }\end{array}$ & $\begin{array}{l}\text { Bifidobacterium Lactobacillus } \\
\text { Streptococcus } \\
\text { Escherichia coli }\end{array}$ \\
\hline Ksylitol & Owoce, grzyby, warzywa, owies, kukurydza & $\begin{array}{l}\text { Bifidobacterium } \\
\text { Streptococcus } \\
\text { Prevotella }\end{array}$ \\
\hline
\end{tabular}

choroby przebiegają z okresami remisji i zaostrzeń. Chociaż etiologia NChZJ nie została w pełni poznana, wiele badań podkreśla wpływ czynników genetycznych, środowiska oraz mikrobioty jelit [13-15]. Liczba przypadków stale rośnie. NChZJ stały się ogólnoświatowym problemem zdrowotnym, a liczba chorych w samej Europie może obecnie wynosić około 2,5-3 mln osób [16]. W Europie współczynniki zapadalności na WZJG sięgają do 24,0 na 100000 osób i do 11,5 na 100000 osób w przypadku choroby LC [17].

Rak jelita grubego (RJG) jest trzecim najczęstszym nowotworem rozpoznawanym $u$ mężczyzn i drugim $u$ kobiet, a także czwartą przyczyną zgonów z powodu raka na świecie. Każdego roku odnotowuje się około 1-2 miliony nowych przypadków RJG, a 600000 osób umiera z tego powodu [18]. Prognozuje się natomiast, że ilość zdiagnozowanych nowych przypadków do 2035 roku wyniesie ponad 2-5 milionów. Większość przypadków nowotworów jelita grubego występuje po 50 roku życia, w krajach rozwiniętych średni wiek zachorowania wynosi około 70 lat [19]. U mężczyzn śmiertelność i zapadalność są około o $25 \%$ wyższe niż u kobiet. Na jego rozpowszechnienie wpływają czynniki geograficzne, częstsze przypadki obserwuje się w krajach najbardziej rozwiniętych [20,21].
Ostatnie badania coraz częściej podkreślają istotny wpływ i rolę SCFA w NChZJ [22] i raku przewodu pokarmowego, zwłaszcza w RJG [23]. W naszej pracy podsumowujemy istniejącą wiedzę na temat SCFA i ich wpływu na zapalenie jelit oraz karcynogenezę.

\section{METABOLIZM SCFA I ICH ROLA W PRZEWODZIE POKARMOWYM}

Stężenie SCFA zmienia się w zależności od odcinka jelita: w proksymalnej części okrężnicy osiąga stężenie w przybliżeniu 70-140 mM, a w dystalnym odcinku okrężnicy spada do 20-70 mM. Wyższe stężenie SCFA w bliższym odcinku okrężnicy jest spowodowane większą dostępnością węglowodanów i wody w tej części jelita

SCFA są wchłaniane przez kolonocyty, głównie poprzez zależne od jonów wodoru i sodu transportery monokarboksylanu (MCTs i SMCTs) [24] oraz poprzez bierną dyfuzję. W tkankach występują różne podtypy i wzorce ekspresji MCT - sprzężony z protonami transporter monokarboksylanu 1 (MCT1/SLC16A1) oraz monokarboksylanowy transporter sprzężony z sodem (SMCT1/SLC5A8). SCFA, które nie są 


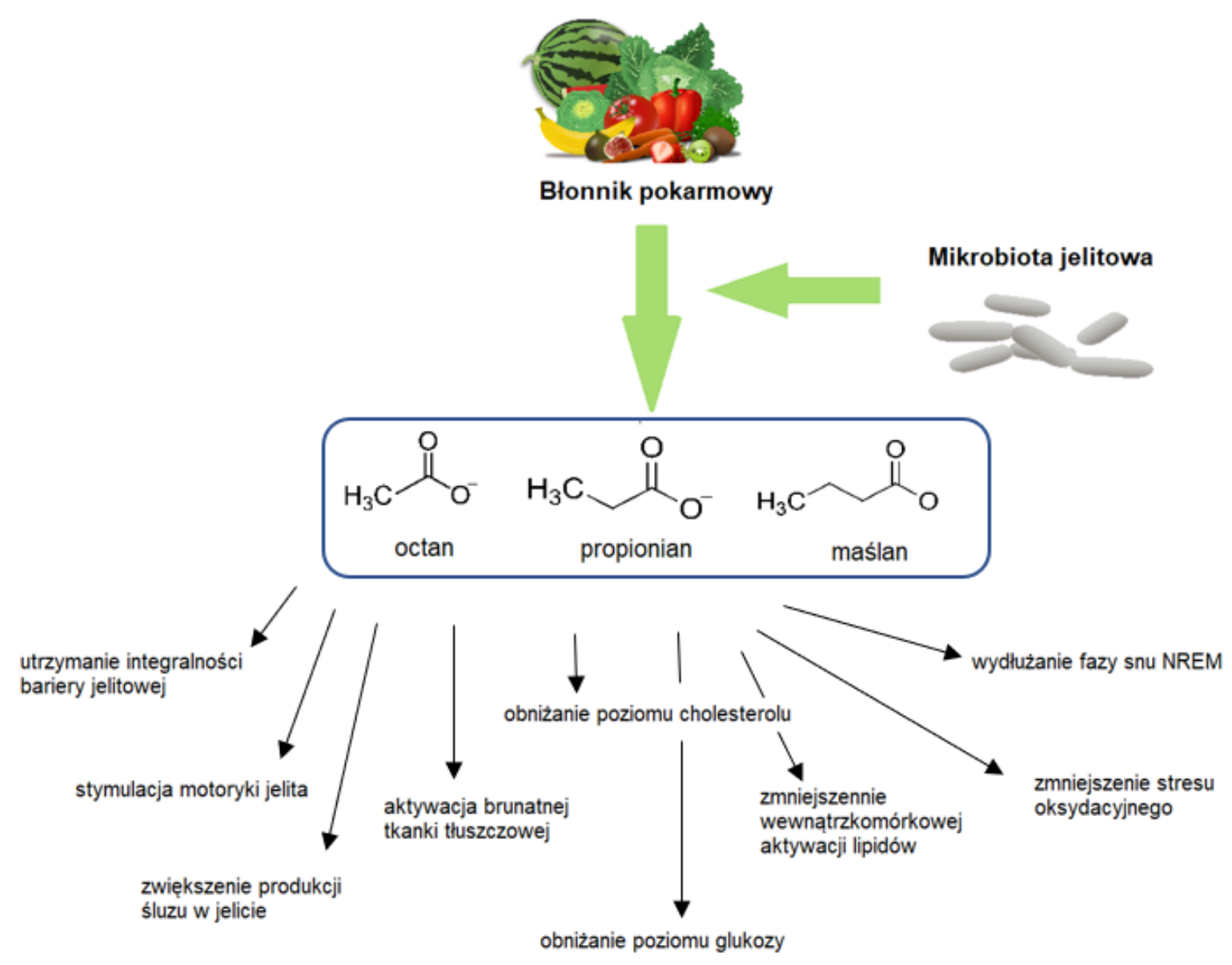

Rycina 1. Wpływ błonnika pokarmowego bogatego w SCFA w organizmie człowieka.

metabolizowane $\mathrm{w}$ kolonocytach, są transportowane do krążenia wrotnego i stanowią źródło energii dla hepatocytów. Jedynie octan nie jest utleniany w wątrobie [25]. Tylko niewielka ilość octanu, propionianu i maślanu dociera to krążenia ogólnoustrojowego oraz innych tkanek takich jak mięśnie szkieletowe czy tkanka tłuszczowa [26]. Większość ostatnich badań dotyczących SCFA wykorzystywało oznaczanie ich stężenia $\mathrm{w}$ kale jako odzwierciedlenie produkcji w okrężnicy [27-32]. Chociaż jest to słuszne podejście, istnieje wiele potencjalnych źródeł błędu, takich jak pasaż jelitowy i przepuszczalność, transport metabolitów i postępowanie z próbkami [33], które należy wziąć pod uwage podczas oceny produkcji SCFA w okrężnicy.

\section{MECHANIZMY DZIAŁANIA SCFA W ORGANIZMIE}

\section{MECHANIZM DZIAŁANIA SCFA \\ ZALEŻNY OD RECEPTORÓW GPCR}

Swoje działanie SCFA wykazują głównie przez aktywację receptorów sprzężonych z białkiem G (ang. G Protein Coupled Receptor, GPCR), do których należą między innymi receptory wolnych kwasów tłuszczowych (ang. free fatty acid receptor, FFAR). Do tej pory udowodniono, że receptory GPR41 (FFAR3), GPR43 (FFAR2), a także GPR109a (HCA2), poprzez działanie SCFA, uczestniczą $\mathrm{w}$ procesie zapalnym oraz karcynogenezie (Ryc. 2). GPR41 i GPR43 stymulowane są przez octan, propionian i maślan, podczas gdy w stymulacji GPR109a biorą udział tylko maślan i niacyna [34,35].

\section{GPR43 (FFAR2)}

Ligandy receptora GPR43 odgrywają istotną rolę w regulacji procesów zapalnych, dodatkowo podejrzewa się, że biorą udział w supresji RJG, jednak działanie to nie zostało jeszcze w pełni poznane.

SCFA działając poprzez GPR43 na nabłonek jelit powodują wypływ kationów potasu, które rozpoczynają hyperpolaryzację komórek okrężnicy, co prowadzi do wydzielania IL-18 przez aktywowany inflamasom NLRP3 [36]. IL-18 pełni kluczową rolę $\mathrm{w}$ utrzymaniu zarówno integralności nabłonka, jak i homeostazy jelitowej [37]. Ponadto SCFA stymulują GPR43 znajdujące się na neutrofilach, tym samym powodując migrację granulocytów obojętnochłonnych podczas procesu zapalnego [38]. Dodatkowo, SCFA biorą udział $\mathrm{w}$ hamowaniu wydzielania cytokin prozapalnych, takich jak TNF alfa [39].

Wiele badań dowiodło, że maślan działając poprzez receptor GPR43 wykazuje działanie przeciwnowotworowe. Indukuje on apoptozę oraz hamuje proliferację zmienionych nowotworowo komórek jelita $[40,41]$. Udowodniono, że w komórkach gruczolakoraka okrężnicy ekspresja receptora 


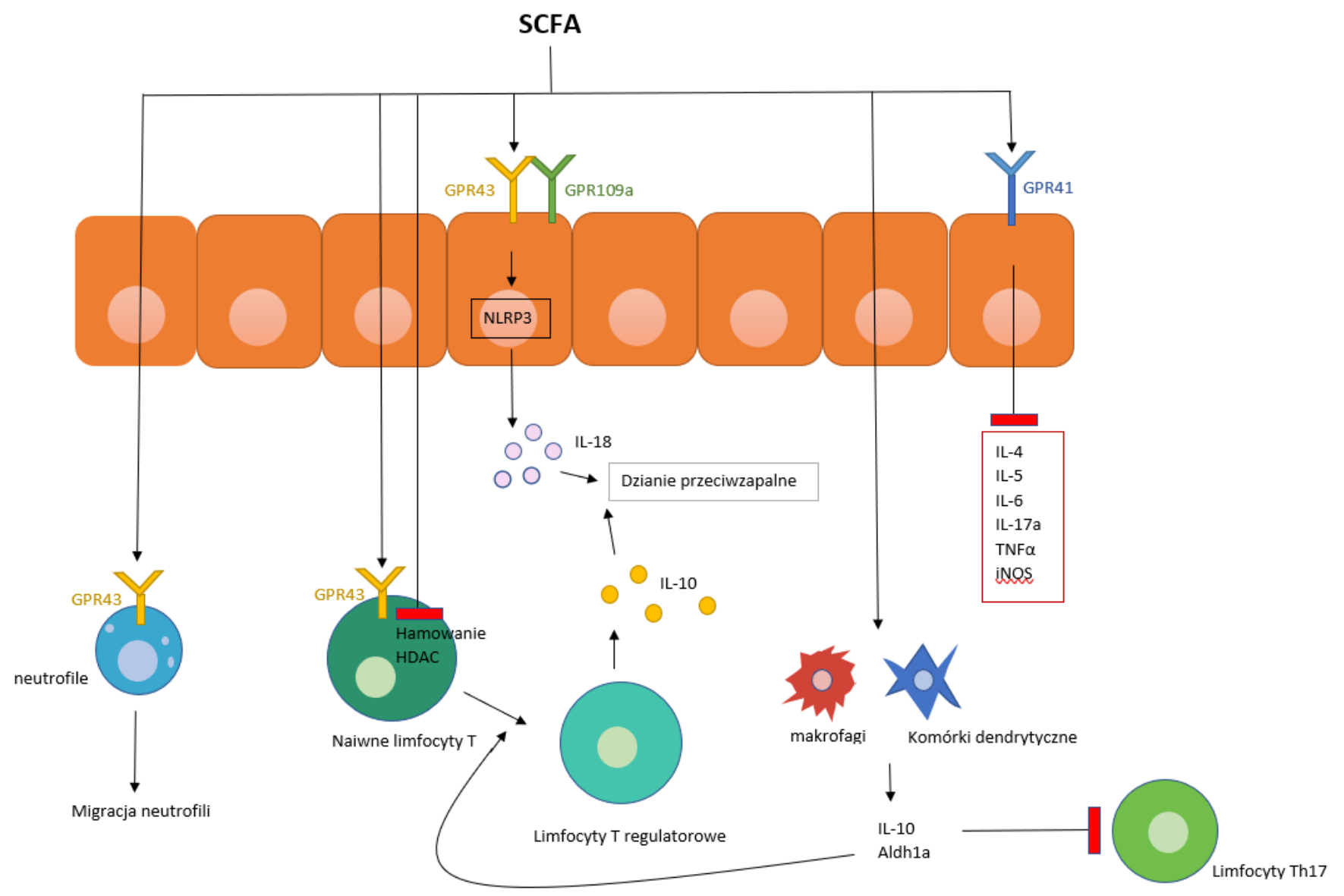

Rycina 2. Mechanizm działania SCFA na receptory GPCR, komórki dendrytyczne, makrofagi i limfocyty.

GPR43 jest obniżona, a ponowna jego aktywacja indukuje apoptozę oraz zatrzymuje cykl komórkowy, co potwierdza, że SCFA działając poprzez GPR43 wykazują działanie przeciwnowotworowe [42]. Potwierdzono to również poprzez badania in vivo. Myszy pozbawione ekspresji receptora GPR43 były bardziej predysponowane do rozwoju RJG w odniesieniu do grupy kontrolnej. Najnowsze badania wykazały, że GPR43 w istotny sposób hamuje HDAC przy udziale maślanu, powodując tym samym epigenetyczną supresję guza $[43,44]$.

Ponadto, stymulacja GPR43 poprawia funkcję jelit poprzez pobudzanie rozwoju korzystnej mikrobioty jelita, np. Bifidobacterium, oraz jednoczesne hamowanie rozrostu niekorzystnego mikrobiomu, np. Helicobacter hepaticus czy Prevotellaceae [45]. Przeprowadzono badania, do których wykorzystano bakterie Clostridium butyricum, które uczestniczą w produkcji maślanu. Wykazano, że bakteria hamowała rozwój nowotworu poprzez modulację ścieżki Wnt/b-katenina. Wyciszenie GPR43 za pośrednictwem siRNA zmniejszyło antyproliferacyjne działanie C. butyricum, co potwierdza potencjalną zależność między aktywacją GPR43 a ochronna rolą tej bakterii [46].

Ponadto odkryto, że obniżona ekspresja receptorów GPR43 sprzyja karcynogenezie poprzez zmniejszenie integralności bariery jelitowej, zmianę ekspresji IL-27 przez komórki dendrytyczne oraz zmianę fenotypu i funkcji limfocytów CD8+ w komórkach rakowych [47].

\section{GPR41 (FFAR3)}

Sugeruje się, że SCFA wykazują efekt przeciwzapalny poprzez działanie na receptor FFAR3. Badania podają, że poprzez oddziaływanie na receptor GPR41 kwas propionowy hamuje ekspresję cytokin prozapalnych, takich jak IL-4, IL-5 oraz IL-17A, natomiast kwas masłowy hamuje ekspresję indukowalnej syntazy tlenku azotu (iNOS), TNFa i IL-6.

\section{GPR109a}

GPR109a jest kolejnym receptorem stymulowanym przez SCFA. Maślan i niacyna poprzez ten receptor indukują nabłonkową transkrypcję IL-18 [48]. Udowodniono, że myszy pozbawione ekspresji GPR109a posiadały obniżony poziom IL-18 w jelicie oraz zwiększoną ilość bakterii z rodziny Prevotellaceae, co wiąże się ze zwiększonym ryzykiem zapalenia okrężnicy. Ponadto, po wywołaniu zapalenia okrężnicy przy użyciu dekstranu siarczanu sodu (DSS), myszy GPR109a -/- rozwinęły ostrzejszy stan zapalny niż myszy WT (ang. Wild Type) [48]. Natomiast agoniści receptora GPR109a w jelicie myszy WT wykazali działanie przeciwzapalne poprzez zmniejszenie aktywacji NF-kb indukowanej przez LPS [49]. 
W liniach komórek raka okrężnicy KM12L4 i HCT116 z ekspresją GPR109a, SCFA hamowały aktywację NF-kb indukowaną przez LPS, natomiast $\mathrm{w}$ komórkach bez ekspresji GPR109a nie wykazywały takiego działania [49]. Dowodzi to, że hamujące działanie maślanu i niacyny zależy od receptora. Ponadto inne badania wykazały, że niedobór GPR109a prowadzi do zapoczątkowania karcynogenezy na podłożu stanu zapalnego jelita [50].

\section{DZIAŁANIE NA SLC5A8}

Slc5a8 jest transporterem zależnym od jonów Na+, który bierze udział w transporcie głównie kwasu masłowego. Uważa się, że Slc5a8 bierze udział w supresji guza okrężnicy zależnej od ilości błonnika $\mathrm{w}$ dostarczonym pożywieniu. W warunkach niskiej podaży błonnika bierze udział w ochronie przed rakiem i zapaleniem okrężnicy, ale gdy spożycie błonnika jest optymalne nie pełni on już tej funkcji. W ten sposób SCFA wpływają na śluzówkowy układ odpornościowy i umożliwiają wspólistnienie mikrobioty w organizmie gospodarza, a tym samym biorą udział $\mathrm{w}$ ochronie przed zapaleniem oraz przed rakiem jelita [51,52].

\section{WPEYW NA MAKROFAGI ORAZ KOMÓRKI DENDRYTYCZNE}

SCFA, poprzez przekształcanie makrofagów M1 w niespolaryzowane makrofagi $\mathrm{M} 0$, hamują proces zapalny komórek odpornościowych. W ten sposób SCFA mogą odgrywać terapeutyczną rolę u chorych na NChZJ [53].

Komórki dendrytyczne (DC) po ekspozycji na kwas masłowy wytwarzają enzymy: 2,3-dioksygenazę indoloaminową 1 (IDO1) i dehydrogenazę aldehydową1A2 (Aldh1A2), a także powodują konwersję naiwnych limfocytów T w Treg. $[51,52]$. Ponadto, kwas masłowy i niacyna mogą indukować wydzielanie IL-10 i Aldh1a w DC i makrofagach, co sprzyja transformacji naiwnych limfocytów T w Treg i hamuje wytwarzanie Th17. Limfocyty Th17 są jednym z typów komórek odpowiedzialnych za indukcję stanu zapalnego i karcynogenezę w jelitach [48, 54-57].

Komórki Treg mają zdolność wytwarzania dużych ilości IL-10, która ma działanie przeciwzapalnie [57]. Badania wykazały, że wśród SCFA, którymi karmiono myszy, to maślan zwiększał poziom Treg w jelicie [58].

\section{DZIAEANIE POPRZEZ HDAC ORAZ LIMFOCYTY CD4+}

SCFA pobudzają limfocyty T CD4+ do produkcji IL-22 oraz stymulują wytwarzanie komórek limfoidalnych poprzez działanie na receptor GPR41. Ponadto, zwiększają produkcję IL-22 poprzez promowanie ekspresji receptora węglowodorów arylowych (AhR) oraz czynnika indukowanego hipoksją 1a (HIF1a), które regulowane są przez mTOR i Stat3. HIF1a wiąże się bezpośrednio z promotorem IL22, a SCFA poprzez modyfikację histonów nasila to wiązanie. Z tego wynika, że suplementacja SCFA zwiększa produkcję IL-22 i poprzez to chroni jelita przed zapaleniem [59]. Dodatkowo SCFA, a przede wszystkim kwas masłowy, maja działanie hamujące na HDAC, tym samym wpływając na geny odpowiedzialne za proliferację, różnicowanie i odpo- wiedź zapalną. Dzięki temu przyczyniają się do utrzymania homeostazy jelita i chronią przed karcynogenezą [60-62]. HDAC reguluje odporność wrodzoną, kontroluje różnicowanie się komórek szpiku oraz odpowiedź zapalną w której pośredniczy ekspresja genów zależnych od TLR i IFN [63]. Ponadto, inhibitory HDAC zmniejszają nasilenie choroby i hamują cytokiny zapalne w okrężnicy, takie jak TNF-a, IFN-g i IL-6, co zostało udowodnione w badaniach na myszach [64]. Te wyniki są obiecujące $\mathrm{w}$ zakresie poszukiwania alternatyw dla terapii NChZJ, szczególnie dla wykorzystania kwasu masłowego jako inhibitora HDAC.

\section{INNE MECHANIZMY DZIAŁANIA SCFA}

SCFA wywołują autofagię linii komórek rakowych jelita HCT116 , SW-480 oraz HT-29 $[65,66]$. Ponadto, SCFA indukują uwolnienie prostaglandyny E2 oraz ekspresję przeciwzapalnej cytokiny poprzez receptor GPCR wrażliwy na PTX (toksyna krztuścowa). W ten sposób hamują odpowiedź zapalną monocytów [67]. Jednakże molekularny mechanizm nie został w pełni poznany.

Inne badania wykazały, że pacjenci chorujący na NChZJ mieli w różnym stopniu obniżony poziom SCFA, co zostało potwierdzone wynikami badania PCR w kierunku butyrylo-CoA [68].

\section{PODSUMOWANIE}

Dzięki wspomnianym mechanizmom SCFA poprawiają integralność błony śluzowej i odpowiedź na proces zapalny. Nieprawidłowa dieta czy choroby jelit, takie jak NChZJ, są związane między innymi z nieprawidłowościami mikrobiomu jelitowego, co przyczynia się do obniżenia poziomu SCFA $[69,70]$. Badania pokazały, że SCFA u pacjentów z WZJG łagodzą stan zapalny [71,72]. Stosowanie SCFA w połączeniu z klasyczną terapią NChZJ przyczyniło się do zwiększenia skuteczności leczenia [73]. Podobnie SCFA produkowane przez mikrobiotę jelitową odgrywają kluczową rolę $\mathrm{w}$ rozwoju raka jelita grubego. Zmiany w stężeniu SCFA, wpływają na liczne mechanizmy związane z karcynogenezą, w tym na adhezję komórek, produkcję cytokin, chemotaksję, rekrutację komórek odpornościowych i apoptozę [74].

Zebrane dane wskazują na korzystny wpływ SCFA na układ odpornościowy jelit, a także stan zapalny i karcynogenezę. Dalsze badania nad rolą SCFA w przewodzie pokarmowym jest kluczowe, aby określić ich dokładną rolę w rozwoju i leczeniu chorób zapalnych i raka jelita grubego.

\section{PIŚMIENNICTWO}

1. Cook SI, Sellin JH (1998) Review Article: Short Chain Fatty Acids in health and disease. Alim Pharmacol Therap 12(6): 499-507

2. Louis P, Flint HJ (2017) Formation of propionate and butyrate by the human colonic microbiota. Environ Microbiol 19: 29-41

3. Macfarlane S, Macfarlane GT (2003) Regulation of short-chain fatty acid production. Proc Nutr Soc 62: 67-72

4. Joseph J, Depp C, Shih Pei-an B, Cadenhead KS, Schmid-Schönbein G (2017) Modified mediterranean diet for enrichment of short chain fatty acids: potential adjunctive therapeutic to target immune and metabolic dysfunction in schizophrenia. Front Neuroscience 11: 155 
5. Brown L, Rosner B, Willett WW, Sacks FM (1999) Cholesterol-Lowering effects of dietary fiber: A meta-analysis. Am J Clin Nutrition 69: 30-42

6. Causey JL, Feirtag JM, Gallaher DD, Tungland BC, Slavin JL (2000) Effects of dietary inulin on serum lipids, blood glucose and the gastrointestinal environment in hypercholesterolemic men. Nutrition Res 20: 191-201

7. Li Z, Yi C, Katiraei S, Kooijman S, Zhou E, Chung CK, Gao Y, Heuvel JVD, Meijer OC, Berbée JFP (2018) Butyrate reduces appetite and activates brown adipose tissue via the Gut-brain neural circuit. Gut 67: 1269-1279

8. Mollica MP, Raso GM, Cavaliere G (2017) Butyrate regulates liver mitochondrial function, efficiency, and dynamics in insulin-resistant obese mice. Diabetes 66: 1405-1418

9. Lewis K, Lutgendorff F, Phan V, Söderholm JD, Sherman PM, McKay DM (2010) Enhanced translocation of bacteria across metabolically stressed epithelia is reduced by butyrate. Inflamm Bowel Dis 16: $1138-1148$

10. Gaudier E, Rival M, Buisine MP, Robineau I, Hoebler C (2009) Butyrate enemas upregulate muc genes expression but decrease adherent mucus thickness in mice colon. Physiol Res 58: 111-119

11. O'Keefe SJD (2016) Diet, Microorganisms and their metabolites, and colon cancer. Nat Rev Gastroenterol Hepatol 13: 691-706

12. Szigethy E, McLafferty L, Goyal A (2010) Inflammatory bowel disease. Child and Adolescent Psychiatric Clinics of North America 19: $301-$ 318

13. Danese S, Fiocchi C (2006) Etiopathogenesis of inflammatory bowel diseases. World J Gastroenterol 12: 4807-4812

14. Kugathasan S, Fiocchi C (2007) Progress in basic inflammatory bowel disease research. Sem Pediatric Surg 16: 146-153

15. Podolsky DK (2002) Inflammatory bowel disease. N Engl J Med 347: 417-429

16. Burisch J, Jess T, Martinato M, Lakatos PL, Ecco E (2013) The burden of inflammatory bowel disease in Europe. J Crohns Colitis 7: 322-337

17. Burisch J, Munkholm P (2015) The epidemiology of inflammatory bowel disease. Scand J Gastroenterol 50(8): 942-951

18. Ferlay J, Shin HR, Bray F, Forman D, Mathers C, Parkin DM, GLOBOCAN (2010) Cancer incidence and mortality worldwide: IARC CancerBase No 10. Lyon: International Agency for Research on Cancer

19. Siegel R, DeSantis C, Virgo K (2012) Cancer treatment and survivorship statistics. CA Cancer J Clin 62: 220-241

20. Bray F, Ferlay J, Soerjomataram I, Siegel RL, Torre LA, Jemal A (2018) Global cancer statistics 2018: GLOBOCAN estimates of incidence and mortality worldwide for 36 cancers in 185 countries. CA Cancer J Clin 68: $394-424$

21. Arnold M, Sierra MS, Laversanne M, Soerjomataram I, Jemal A, Bray F (2017) Global patterns and trends in colorectal cancer incidence and mortality. Gut 66: 683-691

22. Facchin S, Vitulo N, Calgaro M (2020) Microbiota changes induced by microencapsulated sodium butyrate in patients with inflammatory bowel disease. Neurogastroenterol Motil 32(10): 13914

23. Di-Wei Z, Run-Qing L, Jia-Xin A, Tian-Qiu X, Zi-Yi H, Rui X, Yu F, Xian-Zheng $Z$ (2020) Prebiotics-encapsulated probiotic spores regulate gut. Microbiota Suppress Colon Canc Adv Mat 32: 45

24. Vijay N, Morris ME (2014) Role of monocarboxylate transporters in drug delivery to the brain. Curr Pharm Des 20: 1487-1498

25. Schönfeld P, Wojtczak L (2016) Short- and medium-chain fatty acids in energy metabolism: the cellular perspective. J Lipid Res 57: 943-954

26. Cummings JH, Pomare EW, Branch HWJ, Naylor CPE, MacFarlane GT (1987) Short chain fatty acids in human large intestine, portal, hepatic and venous blood. Gut 28: 1221-1227

27. Fung TC, Olson CA, Hsiao EY (2017) Interactions between the microbiota, immune and nervous systems in health and disease. Nat Neurosci 20: $145-155$

28. Sharon G, Sampson TR, Geschwind DH, Mazmanian SK (2016) The central nervous system and the gut microbiome. Cell 167: 915-932
29. Ho L, Ono K, Tsuji M, Mazzola P, Singh R, Pasinetti GM (2018) Protective roles of intestinal microbiota derived short chain fatty acids in Alzheimer's diseasetype beta-amyloid neuropathological mechanisms. Expert Rev Neurother 18: 83-90

30. Skonieczna-Zydecka K, Grochans E, Maciejewska D, Szkup M, SchneiderMatyka D, Jurczak A (2018) Faecal short chain fatty acids profile is changed in Polish depressive women. Nutrients 10: 1939

31. Kelly JR, Minuto C, Cryan JF, Clarke G, Dinan TG (2017) Cross talk: the microbiota and neurodevelopmental disorders. Front Neurosci 11: 490

32. Dinan TG, Cryan JF (2017) The microbiome-gut-brain axis in health and disease. Gastroenterol Clin North Am 46: 77-89

33. Primec M, Micetic Turk D, Langerholc T (2017) Analysis of short-chain fatty ' acids in human feces: a scoping review. Anal Biochem 526: 9-21

34. Brown AJ, Goldsworthy SM, Barnes AA, Eilert MM, Tcheang L, Daniels D (2003) The orphan G protein-coupled receptors GPR41 and GPR43 are activated by propionate and other short chain carboxylic acids. J Biol Chem 278(13): 11312-9

35. Lukasova M, Malaval C, Gille A, Kero J, Offermanns S (2011) Nicotinic acid inhibits progression of atherosclerosis in mice through its receptor GPR109A expressed by immune cells. J Clin Invest 121(3): 1163-73

36. Macia L, Tan J, Vieira AT, Leach K, Stanley D, Luong S, Maruya M, Ian McKenzie C, Hijikata A, Wong C (2015) Metabolite-sensing receptors GPR43 and GPR109A facilitate dietary fibre-induced gut homeostasis through regulation of the inflammasome. Nat Commun 6:1-15

37. Macia L, Tan J, Vieira AT, Leach K, Stanley D, Luong S (2015) Metabolite-sensing receptors GPR43 and GPR109A facilitate dietary fibre-induced gut homeostasis through regulation of the inflammasome. Nat Commun 6: 6734

38. Vinolo MA, Rodrigues HG, Hatanaka E, Hebeda CB, Farsky SH, Curi $R$ (2009) Short-chain fatty acids stimulate the migration of neutrophils to inflammatory sites. Clin Sci (Lond) 117(9): 331-8

39. Vinolo MA, Rodrigues HG, Hatanaka E, Sato FT, Sampaio SC, Curi R (2011) Suppressive effect of short-chain fatty acids on production of proinflammatory mediators by neutrophils. J Nutr Biochem 22(9): 849-55

40. Tang Y, Chen Y, Jiang H, Robbins GT, Nie D (2011) G-protein-coupled receptor for short-chain fatty acids suppresses colon cancer. Int J Cancer 128(4): 847-56

41. Fung KYC, Cosgrove L, Lockett T, Head R, Topping DL (2012) A review of the potential mechanisms for the lowering of colorectal oncogenesis by butyrate. Br J Nutr 108: 820-831

42. Tang Y, Chen Y, Jiang H, Robbins GT, Nie D (2011) G-protein-coupled receptor for short-chain fatty acids suppresses colon cancer. Int J Cancer 128: 847-856

43. Pan P, Oshima K, Huang YW, Agle KA, Drobyski WR, Chen X (2018) Loss of FFAR2 promotes colon cancer by epigenetic dysregulation of inflammation suppressors. Int J Cancer 143: 886-896

44. Pan PW, Skaer C, Wang HT, Oshima K, Huang YW (2017) Loss of free fatty acid receptor 2 enhances colonic adenoma development and reduces the chemopreventive effects of black raspberries in ApcMin/+ mice. Carcinogenesis 38: 86-93

45. Sivaprakasam S, Gurav A, Paschall AV, Coe GL, Chaudhary K, Cai Y (2016) An essential role of Ffar2 (Gpr43) in dietary fibre-mediated promotion of healthy composition of gut microbiota and suppression of intestinal carcinogenesis. Oncogenesis 5: 238-238

46. Chen D, Jin D, Huang S, Wu J, Xu M, Liu T (2020b) Clostridium butyricum, a butyrate-producing probiotic, inhibits intestinal tumor development through modulating Wnt signaling and gut microbiota. Cancer Lett 469: 456-467

47. Lavoie S, Chun E, Bae S, Brennan CA, Gallini Comeau CA, Lang JK (2020) Expression of free fatty acid receptor 2 by dendritic cells prevents their expression of interleukin 27 and is required for maintenance of mucosal barrier and immune response against colorectal tumors in mice. Gastroenterology 158: 1359-1372

48. Singh N, Gurav A, Sivaprakasam S, Brady E, Padia R, Shi H, Ganapathy V (2014) Activation of Gpr109a, receptor for niacin and the com- 
mensal metabolite butyrate, suppresses colonic inflammation and carcinogenesis. Immunity 40: 128-139

49. Thangaraju M, Cresci G, Itagaki S, Mellinger J, Browning DD, Berger FG, Ganapathy V (2008) Sodium-coupled transport of the short chain fatty acid butyrate by SLC5A8 and its relevance to colon cancer. J Gastrointest Surg 12: 1773-1781

50. Wlodarska M, Thaiss CA, Nowarski R, Henao-Mejia J, Zhang JP, Brown EM (2014) NLRP6 inflammasome orchestrates the colonic host-microbial interface by regulating goblet cell mucus secretion. Cell 156(5): 1045-59

51. Gurav A, Sivaprakasam S, Bhutia YD, Boettger T, Singh N, Ganapathy V (2015) Slc5a8, a Na+-coupled high-affinity transporter for short-chain fatty acids, is a conditional tumour suppressor in colon that protects against colitis and colon cancer under lowfibre dietary conditions. Biochem J 469(2): 267-78

52. Miyauchi S, Gopal E, Fei YJ, Ganapathy V (2004) Functional identification of SLC5A8, a tumor suppressor down-regulated in colon cancer, as a $\mathrm{Na}(+)$-coupled transporter for short-chain fatty acids. J Biol Chem 279(14): 13293-6

53. Ji J, Shu D, Zheng M, Wang J, Luo C, Wang Y (2016) Microbial metabolite butyrate facilitatesM2 macrophage polarization and function. Sci Rep 6: 1-10

54. Coombes JL, Siddiqui KR, Arancibia-Carcamo CV, Hall J, Sun CM, Belkaid Y, Powrie F (2007) A functionally specialized population of mucosal CD103+ DCs induces Foxp3+ regulatory T cells via a TGF-beta and retinoic acid-dependent mechanism. J Exp Med 204: 1757-1764

55. Sun CM, Hall JA, Blank RB, Bouladoux N, Oukka M, Mora JR, Belkaid Y (2007) Small intestine lamina propria dendritic cells promote de novo generation of Foxp3 T reg cells via retinoic acid. J Exp Med 204: 1775-1785

56. Liu B, Tonkonogy SL, Sartor RB (2011) Antigen-presenting cell production of IL-10 inhibits T-helper 1 and 17 cell responses and suppresses colitis in mice. Gastroenterology 141: 653-662

57. Rubtsov YP, Rasmussen JP, Chi EY, Fontenot J, Castelli L, Ye X, Rudensky AY (2008) Regulatory T cell-derived interleukin-10 limits inflammation at environmental interfaces. Immunity 28: 546-558

58. Arpaia N, Campbell C, Fan X, Dikiy S, van der Veeken J, deRoos P, Rudensky AY (2013) Metabolites produced by commensal bacteria promote peripheral regulatory T-cell generation. Nature 504: 451-455

59. Yang W, Yu T, Huang X, Bilotta AJ, Xu L, Lu Y, Sun J, Pan F, Zhou J, Zhang W (2020) Intestinal microbiota-derived short-chain fatty acids regulation of immune cell IL-22 production and gut immunity. Nat Commun 11: 4457

60. Riggs MG, Whittaker RG, Neumann JR, Ingram VM (1977) n-Butyrate causes histone modification in HeLa and Friend erythroleukaemia cells. Nature 268: 462-4
61. Boffa LC, Vidali G, Mann RS, Allfrey VG (1978) Suppression of histone deacetylation in vivo and in vitro by sodium butyrate. J Biol Chem 253: 3364-6

62. Davie JR (2003) Inhibition of histone deacetylase activity by butyrate. J Nutr 133: 2485S-93S

63. Shakespear MR, Halili MA, Irvine KM, Fairlie DP, Sweet MJ (2011) Histone deacetylases as regulators of inflammation and immunity. Trends Immunol 32: 335-43

64. Glauben R, Batra A, Fedke I, Zeitz M, Lehr HA, Leoni F (2006) Histone hyperacetylation is associated with amelioration of experimental colitis in mice. J Immunol 176: 5015-22

65. Tang Y, Chen Y, Jiang H, Nie D (2011) Short-chain fatty acids induced autophagy serves as an adaptive strategy for retarding mitochondria-mediated apoptotic cell death. Cell Death Differ 18: 602-18

66. Zhang J, Yi M, Zha L, Chen S, Li Z, Li C (2016) Sodium butyrate induces endoplasmic reticulum stress and autophagy in colorectal cells: implications for apoptosis. PLoS ONE 11: 1-25

67. Cox MA, Jackson J, Stanton M, Rojas-Triana A, Bober L, Laverty M (2009) Short-chain fatty acids act as antinflammatory mediators by regulating prostaglandin E2 and cytokines. World J Gastroenterol 15: 5549-57

68. Lavelle A, Sokol H (2020) Gut microbiota-derived metabolites as key actors in inflammatory bowel disease. Nat Rev Gastroenterol Hepatol 17: $223-237$

69. Scheppach W (1996) Treatment of distal ulcerative colitis with shortchain fatty acid enemas. A placebo-controlled trial. GermanAustrian SCFA study group. Dig Dis Sci 41(11): 2254-9

70. Vernia P, Annese V, Bresci G, d'Albasio G, D'Inca R, Giaccari S (2003) Topical butyrate improves efficacy of 5-ASA in refractory distal ulcerative colitis: results of a multicentre trial. Eur J Clin Invest 33(3): 244-8

71. Scheppach W, Sommer H, Kirchner T, Paganelli GM, Bartram P, Christl S (1992) Effect of butyrate enemas on the colonic mucosa in distal ulcerative colitis. Gastroenterology 103(1): 51-6

72. Sasso GL, Khachatryan L, Kondylis A, Battey JND, Sierro N, Danilova NA, Grigoryeva TV, Markelova MI, Khusnutdinova DR, Laikov AV (2020) Inflammatory Bowel Disease-Associated Changes in the Gut: Focus on Kazan Patients. Inflamm Bowel Dis 27: 418-433

73. Vernia P, Marcheggiano A, Caprilli R, Frieri G, Corrao G, Valpiani D (1995) Short-chain fatty acid topical treatment in distal ulcerative colitis. Aliment Pharmacol Ther 9(3): 309-13

74. Carretta MD, Quiroga J, López R, Hidalgo MA, Burgos RA (2021) Participation of short-chain fatty acids and their receptors in gut inflammation and colon cancer. Front Physiol 12: 662739 


\title{
The role of short-chain fatty acids in inflammatory bowel diseases and colorectal cancer
}

\author{
Jakub Włodarczyk ${ }^{\varpi}$, Martyna Płoska, Karol Płoski, Jakub Fichna
}

Department of Biochemistry, Medical University in Lodz, Łódź, Poland

${ }^{\bowtie}$ Corresponding author: jakub.wlodarczyk@stud.umed.lodz.pl

Keywords: short-chain fatty acids, microbiota, colorectal cancer, inflammatory bowel diseases

Short-chain fatty acids (SCFAs) produced in the human colon are the major products of bacterial fermentation and are believed that they have a protective effect in case of gastrointestinal diseases. SCFAs, such as acetate, propionate, and butyrate are significant metabolites in intestinal homeostasis, and have been shown to be beneficial in inflammatory bowel diseases and colorectal cancer. SCFA are responsible for maintaining proper intestinal barrier and they take part in relevant immune functions. Action of SCFAs is dependent on the activation of protein receptors for receptor activation (GPCR) such as GPR41, GPR43 and GPR109A. In this review, we discuss the effects of SCFA on the intestinal mucosa in terms of inflammatory diseases and colorectal cancer.

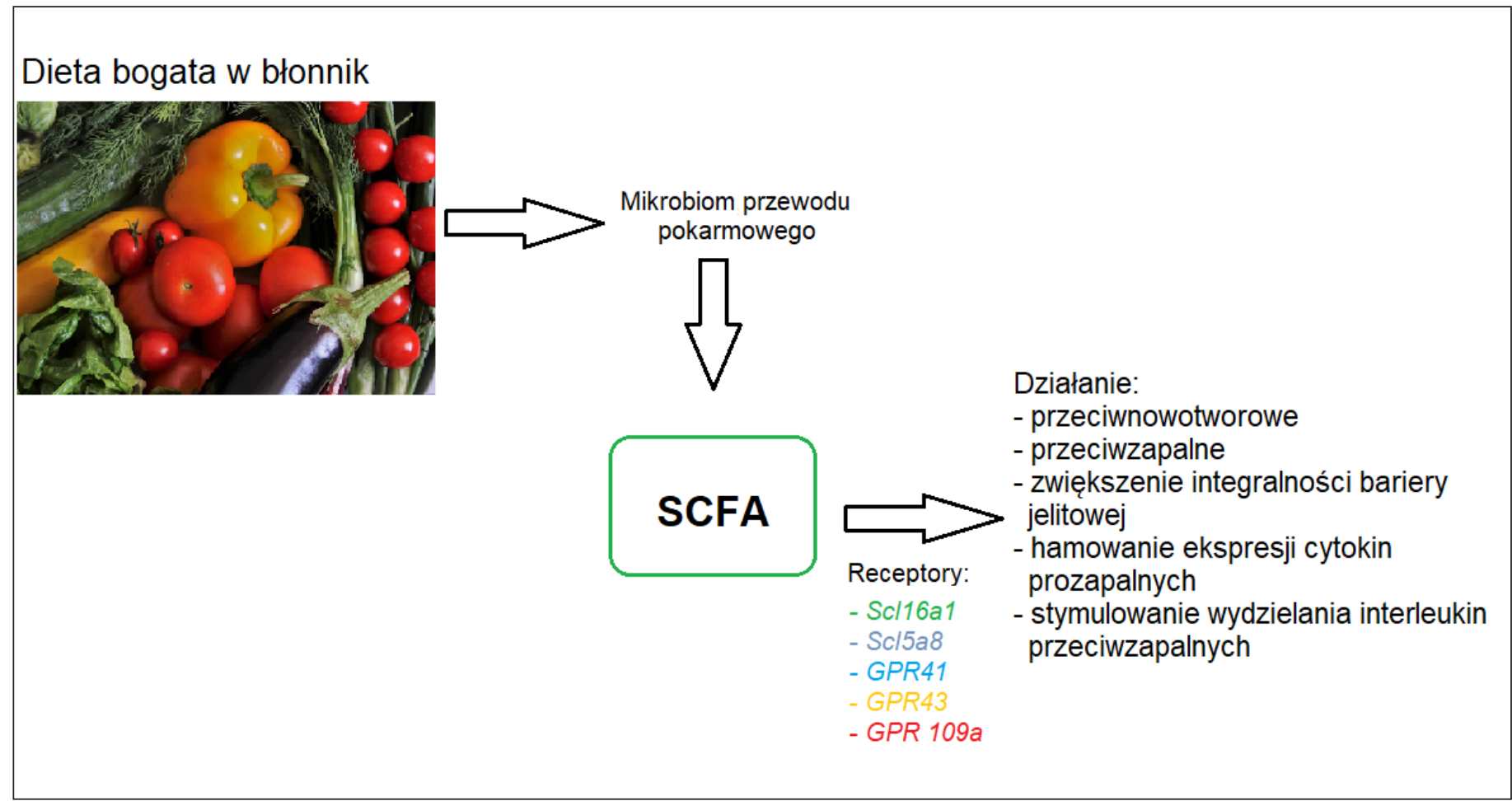

